\title{
Qualitative risk analysis of introducing Batrachochytrium dendrobatidis to the UK through the importation of live amphibians
}

\author{
Alison J. Peel ${ }^{1, *}$, Matt Hartley ${ }^{2}$, Andrew A. Cunningham ${ }^{1}$ \\ ${ }^{1}$ Institute of Zoology, Zoological Society of London, Regents Park, London NW1 4RY, UK \\ ${ }^{2}$ Department for Environment, Food and Rural Affairs, London SW1P 4PQ, UK
}

\begin{abstract}
The international amphibian trade is implicated in the emergence and spread of the amphibian fungal disease chytridiomycosis, which has resulted in amphibian declines and extinctions globally. The establishment of the causal pathogen, Batrachochytrium dendrobatidis $(B d)$, in the UK could negatively affect the survival of native amphibian populations. In recognition of the ongoing threat that it poses to amphibians, $B d$ was recently included in the World Organisation for Animal Health Aquatic Animal Health Code, and therefore is in the list of international notifiable diseases. Using standardised risk analysis guidelines, we investigated the likelihood that $B d$ would be introduced to and become established in wild amphibians in the UK through the importation of live amphibians. We obtained data on the volume and origin of the amphibian trade entering the UK and detected $B d$ infection in amphibians being imported for the pet and private collection trade and also in amphibians already held in captive pet, laboratory and zoological collections. We found that current systems for recording amphibian trade into the UK underestimate the volume of non-European Union trade by almost 10 -fold. We identified high likelihoods of entry, establishment and spread of $B d$ in the UK and the resulting major overall impact. Despite uncertainties, we determined that the overall risk estimation for the introduction of $B d$ to the UK through the importation of live amphibians is high and that risk management measures are required, whilst ensuring that negative effects on legal trade are minimised.
\end{abstract}

KEY WORDS: Amphibian trade $\cdot$ Chytridiomycosis $\cdot$ Risk assessment $\cdot$ Emerging infectious disease

\section{INTRODUCTION}

To avoid the transfer of disease agents the Aquatic Animal Health Code (AAHC) of the World Organisation for Animal Health (OIE) contains standards, guidelines and recommendations for international trade in animals and animal products (OIE 2010a). Before 2008, amphibians were not covered by this code, and no trade recommendations existed.

To address this omission and to make an assessment of the international trade in amphibians, a questionnaire was disseminated to OIE members in
2006 (Schloegel et al. 2010). In its response to the questionnaire, the UK Department for Environment, Food and Rural Affairs (DEFRA) estimated the number of amphibians entering the UK annually to be 5664 from the European Union (EU) and 28002 from non-EU countries. This was based on information from the TRACES (TRAde Control and Expert System) computer application, which records intra- and extra-EU community trade and links all EU animal health and veterinary public health authorities. Historically, a lack of national and international regulations on amphibian movement has meant that this 
and other recording systems do not specifically include amphibians, and therefore data on the global trade in amphibians are incomplete and the figures reported by DEFRA are likely to be underestimates (Schlaepfer et al. 2005, Schloegel et al. 2009, 2010).

Section 8 of the AAHC now provides recommendations for the international trade of amphibians and includes the provision of international aquatic animal health certificates attesting to appropriate testing and treatment of traded amphibians and amphibian commodities. These testing and treatment specifications have not yet been defined. The competent authority in the importing country should assess the import risk posed and apply mitigation measures.

The establishment of the fungal pathogen Batrachochytrium dendrobatidis $(B d)$ in the UK could pose a serious threat to the survival of native amphibian populations (Cunningham et al. 2005, Garner et al. 2009a); therefore, here we provide a qualitative risk analysis for the introduction and establishment of $B d$ in the UK.

\section{MATERIALS AND METHODS}

The AAHC 'provides recommendations and principles for conducting transparent, objective and defensible risk analyses', and, while it does not provide a detailed risk analysis methodology, it outlines 4 necessary components (hazard identification, risk assessment, risk management and risk communication). Risk assessment frameworks are available to implement these components (OIE 2010b) and were recently reviewed for use in freshwater aquatic systems (Thrush et al. 2011). The risk analysis framework used by DEFRA and here is the UK Non-native Organism Risk Assessment (NNRA) scheme (Baker et al. 2005, 2008), which is based on internationally recognised procedures for pest risk assessment developed by the European and Mediterranean Plant Protection Organisation (EPPO) following the International Plant Protection Convention (IPPC) framework. The NNRA scheme aims to assess the potential of non-native species (including specific pathogens) that are absent from all or part of the UK to enter, establish, spread and cause unacceptable impacts. Although terminology varies slightly from the Covello \& Merkhofer (1993) model used by the OIE, and an organism screening step (equivalent to hazard identification) is included within the risk assessment, the processes are otherwise equivalent.

The 3 stages of the NNRA scheme are outlined in Fig. 1 and described in more detail in Baker et al.
STAGE 1: PROCESS INITIATION

\section{STAGE 2: ORGANISM RISK ASSESSMENT}

A. Organism screening

B. Organism assessment

i. Probability of Entry

ii. Probability of Establishment

iii. Potential for Spread

iv. Impact assessment

C. Conclusions of Risk Assessment

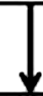

STAGE 3: RISK MANAGEMENT

Fig. 1. Stages and structure of the UK Non-native Organism Risk Assessment (NNRA) scheme

(2008). Briefly, Stage 1 (Initiation) identifies reasons for performing the risk assessment and whether previous risk assessments exist, and defines the risk assessment area. Stage 2, Section A (Organism Risk Assessment) aims to identify whether the organism constitutes a hazard; that is, whether it poses sufficient risk to warrant a detailed risk assessment. If so, Section B then assesses in detail the organism's potential for entry into the risk assessment area via identified pathways, subsequent establishment and spread, and the economic, environmental and social impacts. Finally, overall conclusions of the level of risk and the degree of uncertainty are drawn. Although qualitative risk classifications are based on subjective assessments, standard likelihood and impact terminology are used (Tables 1 to 4 ) and integrated into a likelihood/impact matrix to determine the overall risk (see Table 8).

The level of risk associated with the importation of an organism in the absence of any sanitary measures (the 'unrestricted risk') determines whether risk management measures are required. Organisms with unrestricted risk estimates exceeding 'very low' pose an unacceptable threat, and risk management measures are required. In Stage 3 of the NNRA scheme (Risk Management) sanitary measures aimed at reducing the risk associated with the introduction of $B d$ to the UK are identified, and one or more measures should be selected to achieve an appropriate level of protection (ALOP) or 'acceptable 
Table 1. Risk assessment terminology

\begin{tabular}{|lcl}
\hline Term & Description \\
\hline Likelihood & Probability; the state or fact of being likely \\
Risk & The likelihood of the occurrence and the likely magnitude of the biological and economic \\
& consequences of an adverse event or effect to animal or human health \\
Amphibian & Animal species of the orders Anura and Caudata. The order Gymnophiona was excluded \\
& from consideration in this risk analysis \\
Bd & Batrachochytrium dendrobatidis fungus, known to infect amphibians \\
Chytridiomycosis & The clinical disease of amphibians caused by infection with Bd \\
Pet trade & Trade in amphibians for breeding and private ownership, subdivided into tropical and \\
& temperate amphibians (encompassing a wide range of species and often linked with the \\
& reptile trade) and aquatic amphibians (encompassing a small range of species, e.g. \\
& Hymenochirus boettgeri, and often linked with the ornamental fish trade) \\
Zoo trade & collections \\
Human consumption trade & Trade in live amphibians or amphibian products (e.g. frogs' legs) for human consumption. \\
Gabonerally involves Rana sp., which may be caught in the wild or bred in captivity & Trade in amphibians (generally captive-bred Xenopus sp.) for use in scientific research \\
& laboratories
\end{tabular}

Table 2. UK Non-native Organism Risk Assessment (NNRA) scheme likelihood descriptors for entry and establishment. The responses to all questions about likelihood of entry and establishment are defined for events over a 5 yr period

\begin{tabular}{|ll|}
\hline Likelihood descriptor & Chance of occurrence \\
\hline Very unlikely & $<10 \%$ chance of occurring \\
Unlikely & $10-33 \%$ chance of occurring \\
Moderately likely & $33-66 \%$ chance of occurring \\
Likely & $66-90 \%$ chance of occurring \\
Very likely & $>90 \%$ chance of occurring \\
\hline
\end{tabular}

risk', whilst ensuring that negative effects on trade are minimised.

Throughout the risk assessment process, gaps in current knowledge were addressed by harnessing contributions from relevant stakeholders, the integration of multiple data sources and the incorporation of data from research conducted in 2007 (detailed below). Collaboration between government and non-governmental organisations facilitated this

Table 3. UK Non-native Organism Risk Assessment (NNRA) scheme: confidence descriptors

\begin{tabular}{|ll|}
\hline $\begin{array}{l}\text { Confidence } \\
\text { descriptor }\end{array}$ & Associated level of chance \\
\hline Low & $\sim 35 \%$ chance or less of being correct \\
Medium & $\sim 50 \%$ chance of being correct \\
High & $\sim 80 \%$ chance of being correct \\
Very high & $\sim 90 \%$ chance or better of being correct \\
\hline
\end{tabular}

approach. A summary of the NNRA that we conducted with these data is given below; the full report is available in the supplementary material (Table S1 in the Supplement, available at www.int-res.com/ articles/suppl/d098p095_supp.pdf).

\section{RESULTS}

\section{Stage 1: Process initiation}

Amphibian chytridiomycosis, caused by $B d$, is an emerging infectious disease that threatens amphibian populations worldwide (Mendelson et al. 2006). The global impact of amphibian chytridiomycosis has been described as 'the most spectacular loss of vertebrate biodiversity due to disease in recorded history' (Skerratt et al. 2007). Although the exact geographic source of the pandemic is unknown, molecular data suggest that it resulted from a recent, single lineage outbreak, with subsequent rapid global spread (Fisher et al. 2009a, James et al. 2009). International movements of amphibians for the laboratory, zoo, collector, pet and bait trades, for human consumption, through translocation and release of captivebred amphibians for conservation purposes and from accidental release with other products are implicated as contributing factors (Fisher \& Garner 2007). This risk analysis was initiated after chytridiomycosis was identified as a major threat to amphibian populations worldwide by the OIE ad hoc Group on Amphibian Diseases (OIE 2006). As a result of this threat, and owing to its potential for continued international 
Table 4. UK Non-native Organism Risk Assessment (NNRA) scheme: economic, health, environmental and social impact descriptors

\begin{tabular}{|c|c|c|c|c|c|}
\hline Score & Description & $\begin{array}{l}\text { Monetary loss } \\
\text { and response costs }\end{array}$ & Health impact & Environmental impact & Social impact \\
\hline 1 & Minimal & $<\mathrm{GBE10K} \mathrm{yr^{-1 }}$ & $\begin{array}{l}\text { Local, mild, short-term } \\
\text { reversible effects to } \\
\text { individuals }\end{array}$ & $\begin{array}{l}\text { Local short-term population } \\
\text { loss, no significant } \\
\text { ecosystem effect }\end{array}$ & $\begin{array}{l}\text { No social } \\
\text { disruption }\end{array}$ \\
\hline 2 & Minor & $£ 10 \mathrm{~K}-100 \mathrm{~K} \mathrm{yr}^{-1}$ & $\begin{array}{l}\text { Mild short-term rever- } \\
\text { sible effects to identi- } \\
\text { fiable groups, localised }\end{array}$ & $\begin{array}{l}\text { Some ecosystem impact, } \\
\text { reversible changes, } \\
\text { localised }\end{array}$ & $\begin{array}{l}\text { Significant concern } \\
\text { expressed } \\
\text { at local level }\end{array}$ \\
\hline 3 & Moderate & £100K-1M yr ${ }^{-1}$ & $\begin{array}{l}\text { Minor irreversible effects } \\
\text { and/or larger numbers } \\
\text { covered by reversible } \\
\text { effects, localised }\end{array}$ & $\begin{array}{l}\text { Measurable long-term } \\
\text { damage to populations and } \\
\text { ecosystem, but little spread, } \\
\text { no extinction }\end{array}$ & $\begin{array}{l}\text { Temporary } \\
\text { changes to } \\
\text { normal activities } \\
\text { at local level }\end{array}$ \\
\hline 4 & Major & $£ 1 \mathrm{M}-10 \mathrm{M} \mathrm{yr}^{-1}$ & $\begin{array}{l}\text { Significant irreversible } \\
\text { effects locally or reversible } \\
\text { effects over large area }\end{array}$ & $\begin{array}{l}\text { Long-term irreversible eco- } \\
\text { system change, spreading } \\
\text { beyond local area }\end{array}$ & $\begin{array}{l}\text { Some permanent } \\
\text { change of activity } \\
\text { locally, concern } \\
\text { expressed over } \\
\text { wider area }\end{array}$ \\
\hline 5 & Massive & $>£ 10 \mathrm{M} \mathrm{yr}^{-1}$ & $\begin{array}{l}\text { Widespread, severe, long- } \\
\text { term, irreversible health } \\
\text { effects }\end{array}$ & $\begin{array}{l}\text { Widespread, long-term } \\
\text { population loss or extinction, } \\
\text { affecting several species } \\
\text { with serious ecosystem } \\
\text { effects }\end{array}$ & $\begin{array}{l}\text { Long-term social } \\
\text { change, signifi- } \\
\text { cant loss of employ- } \\
\text { ployment, migration } \\
\text { from affected area }\end{array}$ \\
\hline
\end{tabular}

spread, $B d$ was recently included in the OIE AAHC and therefore added to the list of international notifiable diseases (Schloegel et al. 2010). A recent risk assessment for $B d$ in The Netherlands (Spitzen-van der Sluijs \& Zollinger 2010) identified the risk of $B d$ invasion, settlement and dispersal as high, and the economic, ecological and social impacts of $B d$ in native and captive amphibians as moderate to high, which places it in the highest overall risk category for the assessment method used. No earlier risk assessments exist for the introduction of $B d$ into the UK.

\section{Stage 2: Risk assessment}

\section{Section A: Organism screening}

$B d$ was identified as a potential hazard to the UK for the reasons outlined below, and it was therefore determined that a detailed risk assessment was warranted in order to identify the suitability of national and international amphibian trade and movement regulations.

The organism is known to be invasive in its present range and is threatening species, habitats and ecosystems. $B d$ is highly transmissible and has spread across 6 continents through the international transport of amphibians and via natural means. Infection of some species with $B d$ can occur in the absence of clinical signs (Daszak et al. 2004). In 2010, $B d$ was listed as one of the world's 100 worst invasive species (www.issg.org/database). The 3 amphibian species also on this list, Rhinella marina (= Bufo marinus), Eleutherodactylus coqui and Lithobates catesbeianus (= Rana catesbeiana), are all known to carry $B d$ asymptomatically and can act as effective reservoirs and vectors for transmission of $B d$ locally and internationally (Fisher \& Garner 2007). Amphibian mass mortality events and population declines associated with chytridiomycosis have now occurred globally and the pathogen is known to infect at least 387 species from 37 families and 2 amphibian orders (Anura and Caudata) in at least 45 countries (Fisher et al. 2009a).

$B d$ has become established in populations in new areas outside its original range, as a direct and indirect result of human activities. Amphibian chytridiomycosis, an emerging infectious disease caused by $B d$, has recently increased in incidence, geography and host range (Daszak et al. 1999). Over 50 strains of $B d$ exist globally, yet there is low overall diversity and a lack of geographic structuring of strains, which supports the hypothesis that $B d$ has undergone a rapid and recent range expansion (James et al. 2009). Anthropogenic transcontinental movements of biotic or abiotic reservoirs of $B d$ are likely to have mediated the initial spread of $B d$ into new geographic areas and naive hosts (Rachowicz et al. 2005). Also, Bd is 
known to be highly transmissible in natural environments; for example, it is able to spread via natural watercourses at rates of up to $100 \mathrm{~km} \mathrm{yr}^{-1}$ (Aplin \& Kirkpatrick 2000) and at rates of up to $282 \mathrm{~km} \mathrm{yr}^{-1}$ at continental scales (Lips et al. 2008).

The global trade in live amphibians for human consumption was estimated at greater than 5 million animals per annum in 2006 and is growing rapidly (OIE 2006). The trade in amphibians by collectors and for the pet industry encompasses a much wider range of species and has been estimated at greater than 6 million animals per annum (OIE 2006). Global data for amphibians traded for laboratory use or zoological collections has not been published, but Garner et al. (2009b) indicated that planned amphibian conservation measures will increase amphibian movements from the wild into captivity and among institutions. The potential for pathogens to spread across extensive geographic distances and between captive and wild individuals via the trade of amphibians used as fishing bait was also recently demonstrated (Picco \& Collins 2008).

Although $B d$ occurs outside effective containment in the UK, it is not widely distributed. The extent of $B d$ distribution in the UK is currently unknown. Surveys of native amphibians between 1992 and 1996 found no evidence of the disease in the wild, but $B d$ was detected in wild (introduced) North American bullfrogs Lithobates catesbeianus in Kent in 2004 (Cunningham et al. 2005). This site has undergone a bullfrog eradication programme, and follow-up local and national surveys are underway to assess any $B d$ persistence or further distribution. $B d$ strain virulence is variable and multiple different strains may co-exist within the same geographical area (Berger et al. 2005, Retallick \& Miera 2007, Fisher et al. 2009b, James et al. 2009).

The known geographical distribution of $B d$ includes ecoclimatic zones comparable with those in the UK. $B d$ infection of amphibians has been detected at a wide range of latitudes and altitudes, although environmental conditions associated with chytridiomycosis outbreaks often include cool temperature, high altitude and wet climate (Drew et al. 2006, Fisher et al. 2009a, Kriger \& Hero 2009). Bioclimatic modelling predicting the potential distribution of chytridiomycosis has repeatedly included the UK as an area of high suitability for survival and spread of $B d$ (Ron 2005, Lötters et al. 2009).

Suitable habitat and species vital for the survival, development and multiplication of Bd occur in the UK. The total range of species that can be infected with $B d$ is yet to be determined, but current knowl- edge indicates that all amphibians must be assumed to be at risk. The potential for adaptation of $B d$ strains to local host species and environmental conditions has been demonstrated (Fisher et al. 2009b). In addition to the 10 introduced, non-native species, for example the North American bullfrog, there are 6 extant native amphibian species in the UK and one previously extinct, recently reintroduced species, the northern clade pool frog Pelophylax lessonae (IUCN 2011). Amphibians breeding in permanent water bodies, and particularly in permanent streams, are at the highest risk of becoming infected with $B d$ (Kriger \& Hero 2007, Bielby et al. 2008). Of the 7 amphibian species native to the UK, 6 breed in permanent water bodies. Although $B d$ is a pathogen of amphibians and so requires amphibian hosts for reproduction and establishment, it appears to be able to survive in water or in moist substrate for up to 3 mo in the absence of a host (Johnson \& Speare 2003, Walker et al. 2007).

$B d$ has caused economic and environmental harm elsewhere and has the potential to do the same in the UK. Significant economic value is gained through conservation of biodiversity and maintenance of natural ecosystem services (UK National Ecosystem Assessment 2011). Population declines associated with $B d$ infection pose a serious threat to the survival of amphibians and to ecosystem health; $B d$ is currently the most significant infectious disease threat to biodiversity (Kilpatrick et al. 2010). Additionally, there are significant economic costs involved with mortality, monitoring and surveillance, biosecurity, eradication and control programmes for species conservation efforts.

\section{Section B: Organism assessment}

This risk assessment is focussed on the importation of captive-bred and wild-caught amphibians of the orders Anura (frogs and toads) and Caudata (salamanders and newts). Animals in the remaining amphibian order, Gymnophiona (caecilians) were not included because $B d$ has not been reported in this order and because the volume of trade in caecilians is negligible. Although dead amphibians and fomites, such as water and soil, may harbour and transmit Bd (Berger et al. 1998, Longcore et al. 1999, Nichols et al. 2001, Rachowicz et al. 2005), full assessments of these pathways are outside the scope of this analysis. A basic risk assessment tool to help identify the risk of transferring $B d$ between water bodies through field activities has recently been developed (St-Hilaire et al. 2009) 
Pathways resulting in successful entry, establishment and spread of $B d$ in the UK must include an unbroken chain of events and require that $B d(1)$ is present in the exporting country, (2) survives during transportation, (3) is not detected and killed upon importation, (4) survives during subsequent distribution and housing of imported amphibians, water or other fomites within the UK, (5) is released and this results in exposure to wild amphibians, (6) infects wild amphibians and (7) becomes established and self-perpetuating in natural environments. Potential pathways are assessed below.

Probability of entry of $\boldsymbol{B d}$ and exposure to amphibians in the UK. Identification of entry pathways: Pathways by which $B d$ could be introduced to the UK from non-EU countries and EU member states were identified and are summarised in Fig. 2. Legal entry may originate from within or outside the EU and be destined for the pet (including private collection) trade, zoos, laboratories or human consumption (Fig. 2, Boxes 1a-d). Entry may also be via illegal or unintentional movements (Fig. 2, Boxes 1e-g). Methods used to assess the true volume of the amphibian trade into the UK and the prevalence of $B d$ infection in amphibians in each pathway are outlined below. Data on illegal trade and unintentional movements is scarce and is considered only briefly.

Consignments of live amphibians, reptiles and fish originating from non-EU Countries can only legally be received by 3 UK border inspection posts (BIPs): Heathrow, Gatwick and Manchester airports (Fig. 2, Boxes 2a \& 3a). According to TRACES, Heathrow receives almost $85 \%$ of these consignments. Amphibians may also enter unreported via any international air, rail or shipping port from within the EU (Fig. 2, Boxes $2 b$ \& $3 b$ ) or from non-EU countries if fewer than 5 individuals are imported and are accompanied by a person. Amphibians can legally enter the UK with reptiles or fish as mixed consignments (Fig. 2, Box 4b). Reptile and fish consignments must be imported via BIPs and recorded by TRACES under their relevant commodity codes (010620 and 0301, respectively). Whilst the reptile and fish import data are transferred from hardcopy Common Veterinary Entrance Document for Animals (CVEDAs) and invoices into TRACES, amphibian import data are only transferred to TRACES for amphibian-only consignments (Fig. 2, Box 5a).
Two methods of ascertaining amphibian trade volume were compared. Firstly, the database of electronic submissions for the CVEDAs were searched by using TRACES for consignments entering the UK in 2006 with the commodity code 010690 ('Other live animals', which include Amphibia, Annelida, Arachnida, Hymenoptera, Myriapodae and other Insecta); the consignments were then filtered by the species class 'amphibia'. This was the source of the withinEU trade figures submitted by DEFRA for the 2006 OIE questionnaire. TRACES recorded 22825 amphibians entering the UK in 2006; however, these data are flawed and of limited value. Within this commodity code, only those species requiring health certificates (bees) or those listed by the Convention on International Trade of Endangered Species (CITES) are required to be recorded on TRACES. When the TRACES entries were examined in detail, it was estimated that these 'amphibian' consignments actually contained only 1000-1200 amphibians.

To assess the quantity of unrecorded amphibian imports, we searched hard-copy CVEDA, health certificate and invoice archives for every fish, reptile and amphibian consignment that entered Heathrow airport from a non-EU country in 2006 ( $\mathrm{n}=2368$ consignments). If live amphibians were present in the consignment, species and individual numbers were extracted from the relevant company invoice.

Using this method we estimated the number of amphibians entering the UK through Heathrow in 2006 as 111464 (Table 5). Assuming mixed amphibian, reptile and fish consignments that passed through Gatwick and Manchester airports contain comparable proportions of unrecorded amphibians as those that pass through Heathrow, we estimated, by extrapola-

Table 5. Numbers of amphibians imported into the UK in 2006 from non-EU countries via Heathrow Animal Reception Centre (HARC; which handles 85\% of UK amphibian imports) assessed using 2 methods (numbers of consignments indicated in parentheses). TRACES: Trade Control and Expert System

\begin{tabular}{|c|c|c|c|}
\hline \multirow[t]{2}{*}{ Source } & \multicolumn{2}{|c|}{ HARC estimates -} & \multirow[t]{2}{*}{ UK estimate } \\
\hline & Paper-based & TRACES & \\
\hline Pet trade & $108726(306)$ & & $128366(361)$ \\
\hline $\begin{array}{l}\text { In amphibian } \\
\text { consignments }\end{array}$ & $1475(8)$ & $22825(83)$ & $1741(9)$ \\
\hline In reptile consignments & $25296(114)$ & & $29865(135)$ \\
\hline In fish consignments & $81955(184)$ & & $96759(217)$ \\
\hline Laboratory trade & $2708(23)$ & & $3197(27)$ \\
\hline Zoo trade & $30(3)$ & & $35(4)$ \\
\hline Total & $111464(332)$ & $22825^{\mathrm{a}}(83)$ & $131599(392)$ \\
\hline
\end{tabular}



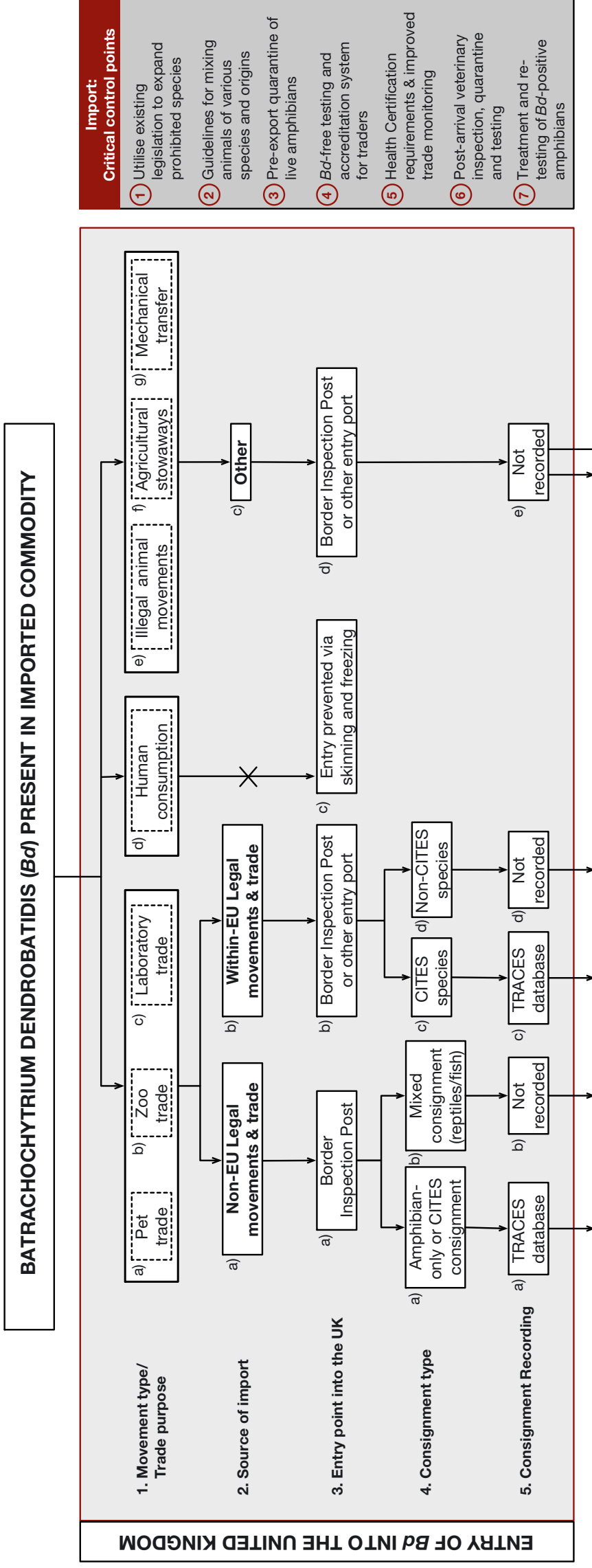

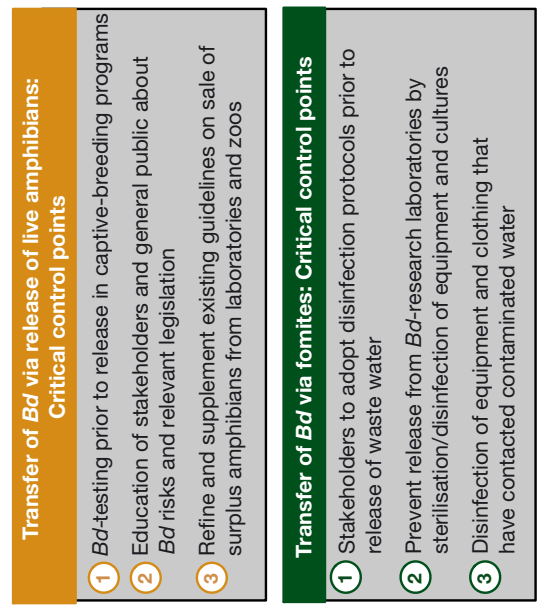

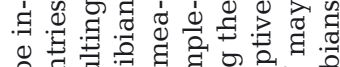

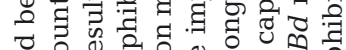

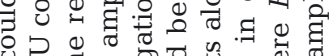

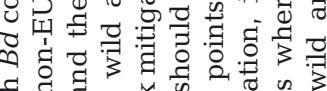

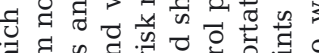

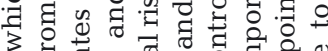

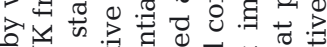
ज

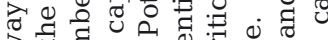
3 웡

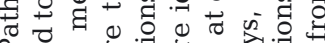

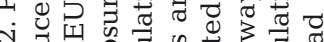

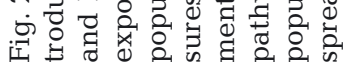
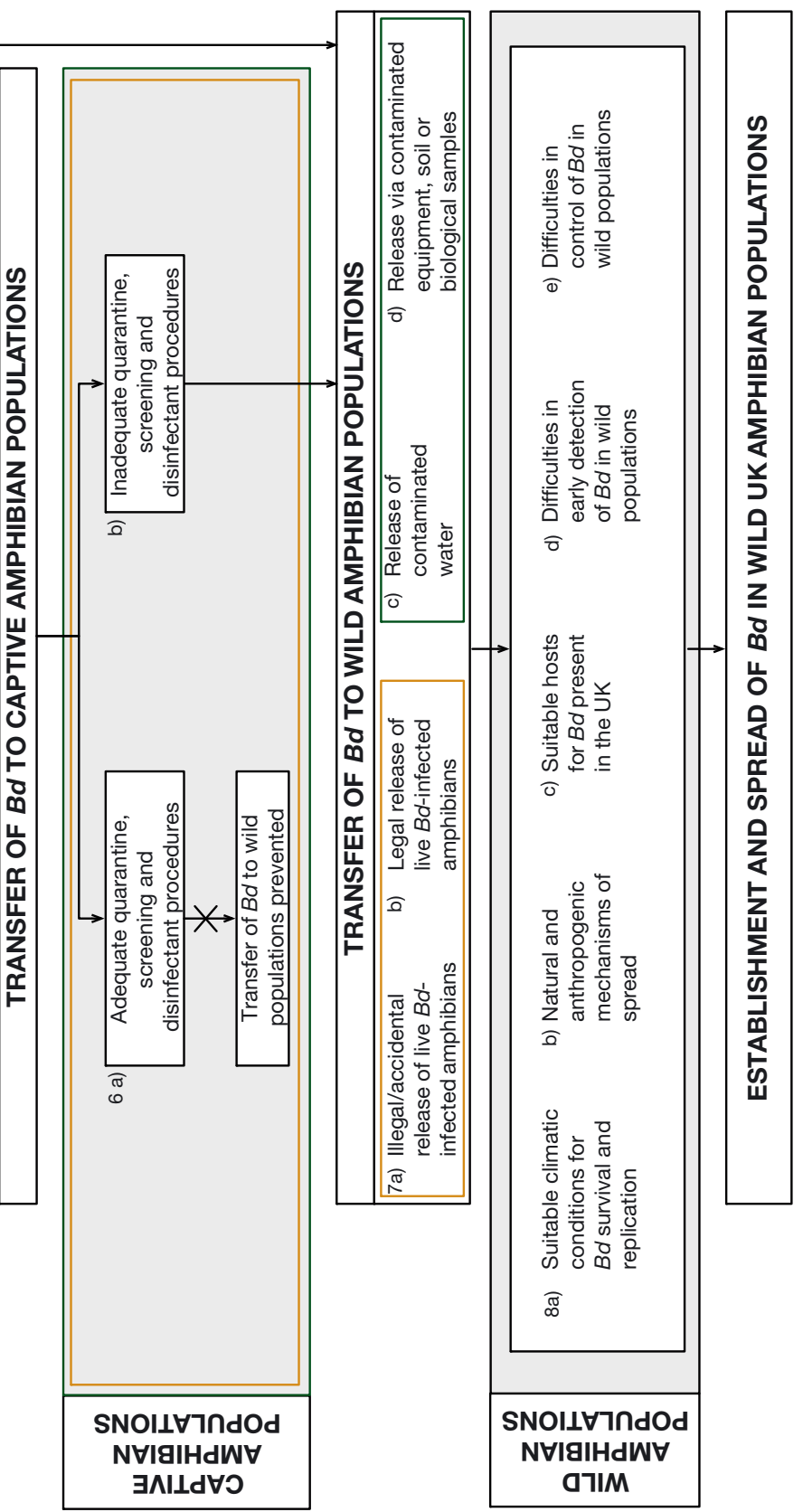
tion, the total number of live amphibians imported legally into the UK from non-EU countries via the 3 BIPs in 2006 as 131599, which is at least 10-fold greater than the number of imported amphibians accurately recorded on TRACES during this period.

Based on species, commodity code and declared purpose, live amphibians entering the UK via Heathrow were predominantly imported for the pet trade (including private collectors) (97.5\%). Only $1.3 \%$ of imported animals were in amphibianspecific consignments, of which the vast majority $(73.5 \%)$ were aquatic species that entered in consignments consisting predominantly of fish. Trade for laboratory use $(2.4 \%)$ and zoo collections $(<0.1 \%)$ was low. No consignments of live amphibians in 2006 were specified for human consumption.

Amphibians may enter the UK from the EU via BIPs (Fig. 2, Box 3b); however, this is not required unless they are CITES species. Entry of CITES species is recorded on TRACES (Fig. 2, Boxes 4c \& 5c), but within-EU trade of non-CITES species is not recorded at all (Fig. 2, Boxes 4d \& 5d). Information from the UK-based Reptile and Exotic Pet Trade Association (REPTA) indicates that unrecorded EU trade consists primarily of private owners returning from amphibian shows in The Netherlands and Germany with small numbers of amphibians for private collections (C. Newman pers. comm.). These animals may be caught in the wild or bred in captivity in Europe, or may have originated from a non-EU country.

To assess the prevalence of $B d$ infection in amphibians entering the UK through BIPs, testing was performed on a subset of amphibians at the time of importation and within the trade for each of the 3 major entry pathways for live amphibians (legal importation for the pet, zoo and laboratory trades) (Table 6). In June 2007, 445 individuals from 67 species were skin-swabbed (on ventral abdomen, hind legs and feet) according to the methods described by Hyatt et al. (2007). All samples were processed using the quantitative real-time PCR (qPCR) method described by Boyle et al. (2004). Inclusion of standards and replicates was performed as per Garner et al. (2006). The qPCR method is highly sensitive and highly specific in detecting $B d$ zoospores, and is the preferred diagnostic technique when the primary interest is in 'detecting the absolute presence of $B d$ regardless of the number of zoospores detected' (Kriger et al. 2006a, Smith 2007). Additional benefits include improved speed and automation when compared with standard PCR, histology or immunohistochemistry techniques. However, qPCR also has disadvantages: given its exquisite sensitivity, conta- mination in the field or lab can result in false positives, and the detection of $B d$ genetic fragments does not necessarily imply infection of that individual or the presence of live fungus. (For further opinion on the use of qPCR for the detection of $B d$, see Kriger et al. 2006a,b, 2007, Smith 2007).

The prevalence of $B d$ infection varied across the different entry pathways, from 0 to $23.5 \%$, and was highest in the laboratory trade $(23.5 \%)$, followed by the zoo trade $(5.9 \%)$, and was lowest in amphibians in the pet trade (0 to $3.2 \%$ ) (Table 3 ). Infection with $\mathrm{Bd}$ was detected in 2 species in which it has not been previously described (Pyxcicephalus adspersus and Theloderma corticale) (www.spatialepidemiology.net/ bd-maps/surveillance/). Bd infection has not previously been reported in the UK in the remaining positive-testing species, Hyperolius tuberlinguis, Xenopus laevis and Silurana tropicalis, although infection in all 3 of these species has been reported elsewhere (Reed et al. 2000, Weldon et al. 2004, Kielgast et al. 2010).

These prevalence data carry a high degree of uncertainty. Selection biases were present, and sampling sizes from aquatic species in the pet trade and the laboratory trade were small (both $\mathrm{n}=10$, Table 7). Sampling was aimed at collecting preliminary data and a larger, structured sampling programme is required to give true prevalence estimates. These results do, however, show that $B d$-positive animals are being imported into the UK from EU and non-EU countries through the live amphibian trade.

Assessment of entry pathways: Each pathway in Fig. 2 was assessed to determine the likelihood of $B d$ entering the UK via the importation of $B d$-infected amphibians, contaminated water or other fomites, and subsequent exposure to both captive and wild amphibians. Common components of the import pathways are addressed first and apply across all pathways unless otherwise specified.

Generic risk. There is a high likelihood that $B d$ would survive transportation conditions as the fungus can survive a wide range of environmental temperatures (Bradley et al. 2002, Piotrowski et al. 2004) and no specific pre- or post-export measures, such as testing, treatment or disinfection, are currently required to reduce the likelihood of $B d$ introduction (OIE 2010a). Clinical signs of $B d$ infection may be absent or non-specific and sensitive laboratory testing is required for a definitive diagnosis (Kriger et al. 2007); therefore, it is very likely that infected amphibians will enter the UK undetected under the existing regime.

Pet trade (including private collections). It is likely that $B d$ could be imported in the pet trade from areas 
Table 6. Prevalence of qPCR-detected Bd infection in amphibians entering the UK, tested at the time of importation and within each trade sector. HARC: Heathrow Animal Reception Centre; na: not applicable

\begin{tabular}{|c|c|c|c|c|c|}
\hline $\begin{array}{l}\text { Method of } \\
\text { trade }\end{array}$ & Location & $\begin{array}{l}\text { Amphibians } \\
\text { tested }\end{array}$ & Selection method & $\begin{array}{l}\text { Positive results } \\
(\%, 95 \% \mathrm{CI})\end{array}$ & $\begin{array}{l}\text { Trade } \\
\text { prevalence }\end{array}$ \\
\hline \multirow[t]{3}{*}{$\begin{array}{l}\text { Pet trade: } \\
\text { terrestrial or } \\
\text { semi-aquatic } \\
\text { species }\end{array}$} & HARC & $\begin{array}{l}109 \text { individuals } \\
\text { from mixed reptile } \\
\text { and amphibian } \\
\text { consignments }\end{array}$ & $\begin{array}{l}\text { Opportunistic sampling } \\
\text { of consignments. Maxi- } \\
\text { mum (max.) } 10 \text { samples } \\
\text { per consignment, max. } \\
5 \text { samples per species, } \\
\text { randomly selected }\end{array}$ & $\begin{array}{l}4 \text { out of } 109 \\
(3.7 \%, 0.1-7.2 \%) \\
\text { USA: Pyxcicephalus } \\
\text { adspersus, Pseudacris crucifer } \\
\text { Tanzania: Hyperolius argus, } \\
\text { H. tuberlinguis }\end{array}$ & $\begin{array}{l}3.2 \% \\
(0.4-5.9 \%)\end{array}$ \\
\hline & $\begin{array}{l}\text { Amphibian } \\
\text { trade } \\
\text { shows }\end{array}$ & 14 individuals & $\begin{array}{l}\text { Max. } 5 \text { samples per } \\
\text { species randomly selec- } \\
\text { ted from willing traders } \\
\text { in } 2 \text { shows }\end{array}$ & $\begin{array}{l}1 \text { out of } 14(7.1 \%,-6.3-20.6 \%) \\
\text { UK captive bred: } \\
\text { Bombina variegata }\end{array}$ & \\
\hline & Pet shops & 34 individuals & $\begin{array}{l}\text { Pet shops selected known } \\
\text { to sell large numbers of } \\
\text { amphibians. All species } \\
\text { held were tested, max. } 5 \\
\text { samples per species, ran- } \\
\text { domly selected }\end{array}$ & 0 out of $34(0 \%)$ & \\
\hline \multirow[t]{2}{*}{$\begin{array}{l}\text { Pet trade: } \\
\text { aquatic } \\
\text { species }\end{array}$} & HARC & $\begin{array}{l}10 \text { individuals } \\
\text { from a mixed fish } \\
\text { and amphibian } \\
\text { consignment }\end{array}$ & $\begin{array}{l}\text { Opportunistic sampling } \\
\text { of single consignment, } \\
\text { individuals randomly } \\
\text { selected }\end{array}$ & 0 out of $10(0 \%)$ & $0 \%$ \\
\hline & Pet shop & 7 individuals & $\begin{array}{l}\text { Pet shops selected known } \\
\text { to sell large numbers of } \\
\text { amphibians. All species } \\
\text { held were tested, max. } 5 \\
\text { samples per species, } \\
\text { randomly selected }\end{array}$ & 0 out of $7(0 \%)$ & \\
\hline Zoo trade & $\begin{array}{l}\text { Archived } \\
\text { records }\end{array}$ & $\begin{array}{l}237 \text { records ana- } \\
\text { lysed from } 2005 \\
\text { to } 2007 \text { from UK } \\
\text { zoos }\end{array}$ & $\begin{array}{l}\text { All records analysed from } \\
11 \text { institutions of animals } \\
\text { in quarantine before intro- } \\
\text { duction into collection }\end{array}$ & $\begin{array}{l}14 \text { out of } 237 \\
(5.9 \%, 2.9-8.9 \%) \\
\text { Dyscophus antongilii, } \\
\text { Theloderma corticale, } \\
\text { Xenopus laevis }\end{array}$ & $\begin{array}{l}5.9 \% \\
(2.9-8.9 \%)\end{array}$ \\
\hline \multirow[t]{2}{*}{$\begin{array}{l}\text { Laboratory } \\
\text { trade }\end{array}$} & HARC & $\begin{array}{l}10 \text { individuals from } \\
\text { an amphibian } \\
\text { consignment }\end{array}$ & $\begin{array}{l}\text { Opportunistic sampling of } \\
\text { single-species consign- } \\
\text { ment, individuals } \\
\text { randomly selected }\end{array}$ & 0 out of $10(0 \%)$ & $\begin{array}{l}23.5 \% \\
(9.3-37.8 \%)\end{array}$ \\
\hline & $\begin{array}{l}\text { Research } \\
\text { laboratory } \\
\text { stock }\end{array}$ & $\begin{array}{l}23 \text { individuals } \\
\text { individually housed } \\
\text { with a recirculating } \\
\text { water system. One } \\
\text { archived record }\end{array}$ & $\begin{array}{l}\text { University research labo- } \\
\text { ratory. } 13 \text { samples from } \\
X . \text { laevis and } 10 \text { samples } \\
\text { from Silurana }(X .) \text { tropicalis, } \\
\text { randomly selected. } \\
\text { Archive: } X . \text { laevis }\end{array}$ & $\begin{array}{l}7 \text { out of } 23 \text { swabs }+1 \text { out of } 1 \\
\text { archived record }(33.3 \%, 14.5- \\
52.2 \%) \text { USA captive bred: } \\
X . \text { laevis, S. tropicalis }\end{array}$ & \\
\hline $\begin{array}{l}\text { Human } \\
\text { consumption }\end{array}$ & na & $\begin{array}{l}\text { No testing } \\
\text { performed }\end{array}$ & na & na & \\
\hline Total & & $\begin{array}{l}207 \text { swabs, } \\
238 \text { records }\end{array}$ & & $\begin{array}{l}12 \text { out of } 207 \text { swabs } \\
(5.8 \%, 2.6-9.0 \%) \\
15 \text { out of } 238 \text { records } \\
(6.3 \%, 3.2-9.4 \%)\end{array}$ & $\begin{array}{l}6.1 \% \\
(3.8-8.3 \%)\end{array}$ \\
\hline
\end{tabular}

where the pathogen is extant (Fig. 2, Box 1a). The mixing of amphibians of various species and origins occurs frequently at various stages in this pathway; this enables pathogen transmission and increases the likelihood of imported animals being infected with
$B d$. Even amphibians within a single consignment may have been mixed from different areas within the country of origin before export, and consignments may contain multiple species within one container (R. Quest pers. comm.). Imports generally pass 
Table 7. Summary of risk assessment for the entry, establishment and spread of $B d$ in the UK

\begin{tabular}{|c|c|c|c|}
\hline Source & Likelihood & Confidence & Explanation \\
\hline Pet trade & Likely & Very high & High trade volume, high presence of $B d$ \\
\hline Zoo trade & Moderately likely & High & Low trade volume, disease screening exists \\
\hline Laboratory trade & Likely & High & Moderate trade volume, known presence of $B d$ \\
\hline Human consumption & Very unlikely & High & Legislation and trade practices remove $B d$ \\
\hline Illegal movements & Moderately likely to likely & Low & Uncontrolled trade, release likely \\
\hline Unintentional transfer & Moderately likely & Medium & Low trade volume, but $B d$ survival likely \\
\hline \multicolumn{4}{|l|}{ Summary } \\
\hline Entry & Very likely & Very high & $\begin{array}{l}\text { Entry was determined as likely via multiple } \\
\text { pathways }\end{array}$ \\
\hline Establishment & Likely & High & $\begin{array}{l}\text { Bd previously established in the UK, suitable } \\
\text { conditions still exist }\end{array}$ \\
\hline Spread & Moderately likely & Medium & Dependent on suitability of site of release \\
\hline
\end{tabular}

through a wholesale distributor before purchase by retailers, collectors or breeders (C. Newman pers. comm.), and quarantine measures to prevent $B d$ transmission are frequently inadequate (A. J. Peel pers. obs.) (Fig. 2, Box 6b).

In 2006, the trade volume of amphibians imported for the pet trade comprised $97.5 \%$ of total UK amphibian imports and was estimated at 128366 amphibians per year (Table 5). Approximately 6 consignments were imported into the UK each week. Three-quarters of these imports were aquatic amphibians that entered within live fish consignments. According to the records we analysed at Heathrow BIP, little species diversity existed in the amphibians entering via this route: imports were predominantly Hymenochirus spp. (68\%), Cynops spp. (16\%) and Xenopus spp. (11\%), and all entered from China, Singapore or Hong Kong. Although Bd-infected species were not identified in the amphibian trade in Hong Kong (Rowley et al. 2007), infected native and invasive species recently have been detected in China (Bai et al. 2010). Xenopus spp. and Hymenochirus boettgeri are known reservoirs and vectors of $B d$ (Fisher \& Garner 2007). Bd infection has been reported in captive $H$. boettgeri, and a high prevalence of $B d$ infection was recently reported in Cynops ensicauda in Japan (Raverty \& Reynolds 2001, Fisher \& Garner 2007, Goka et al. 2009). In the current study, no aquatic amphibians with $B d$ infection were detected by skin-swab sampling at Heathrow BIP or at pet shops in the $\mathrm{UK}_{\text {; }}$ however, the total sample size was low $(\mathrm{n}=17)$.

The remaining $25 \%$ of amphibians entering the UK for the pet trade were imported with reptiles or in amphibian-only consignments and comprised a wide variety of mainly terrestrial or semi-aquatic species ( $\mathrm{n}=101$ species). We detected $B d$ infection in $3.2 \%$ of amphibians in these consignments at Heathrow BIP, and 4 out of $20(20 \%)$ consignments contained $B d-$ infected amphibians. By extrapolation to all 3 BIPs, we estimated that approximately $1120 B d$-infected amphibians entered the UK in amphibian-only or in mixed reptile and amphibian consignments for the pet trade in 2006. Because an estimated 144 reptile and amphibian consignments enter the UK per year, more than one consignment per fortnight is likely to contain a $B d$-infected amphibian.

Exotic amphibians are often released from captivity, intentionally or unintentionally, into sites such as garden ponds where they can come into direct or indirect contact with wild amphibians (Fig. 2, Box 7a) (Holsbeek et al. 2008, 2010). These live amphibian releases, in addition to practices such as cleaning out vivaria into gardens where there is no waste water treatment (Fig. 2, Boxes $7 \mathrm{c}, \mathrm{d}$ ), could result in the transfer of $B d$ into local environments and the subsequent exposure of native amphibians to the fungus. Overall, we concluded that $B d$ entry and exposure to amphibian populations via the pet trade pathway is likely (Table 7).

Zoo trade. It is probable that $B d$ could be present in wild-caught amphibians imported for zoos from areas where $B d$ is extant (Fig. 2, Box 1b). Captivebred amphibians from collections that have monitoring and control protocols for detecting $B d$ infection are less likely to be infected with $B d$. Although adequate testing will probably detect $B d$ if present, specific quarantine procedures and diagnostic testing are not standard practice in most zoos. A review of testing records conducted at the Institute of Zoology on zoo amphibians tested from a range of UK zoos indicated an overall prevalence of $5.9 \%$ (A. J. Peel \& A. A. Cunningham unpubl. obs.). The recorded volume of the zoo trade into the UK is negligible in com- 
parison with the pet trade (an estimated 35 versus 128366 individuals in 2006; Table 5), although it is likely that some zoo stock is sourced from the pet trade or from private collectors.

Owing to the general lack of $B d$ control measures conducted by zoos (Fig. 2, Box 6b) and the large geographic and species range of zoo amphibians, we estimate a high likelihood of $B d$-infected amphibians held in zoos will be released into the wild in the absence of specific mitigating actions. This is known to have occurred for at least one conservation programme (Walker et al. 2008). This could occur, for example, by the release of animals that were infected during captivity or from the use of contaminated field equipment (Fig. 2, Boxes 7b-d). Although the number of intentional zoo animal releases is low, when they do occur animals usually are released into prime amphibian (and hence $B d$ ) habitat in the presence of sympatric species; therefore, this pathway was assessed as being moderately likely to result in entry of $B d$ and its exposure to wild and captive amphibian populations (Table 7).

Laboratory trade. Purpose-bred laboratory amphibians entering the UK from reputable establishments (Fig. 2, Box 1c) are likely to be monitored for clinical signs of disease. The species most commonly involved in the laboratory trade (Xenopus laevis), however, is an asymptomatic carrier of $B d$ (Fisher \& Garner 2007) and routine testing for $B d$ infection in this pathway is not known to take place (Fig. 2, Box 6a). Also, as infected $X$. laevis often have low infection loads of $B d$, infection could remain undetected even with specific testing.

The estimated number of laboratory amphibians imported into the UK in 2006 was 3197 (Table 5). Sampling at Heathrow did not identify any infected amphibians; however, in one laboratory animal facility tested, captive stock housed individually with a recirculating water system had a high prevalence of $B d$ infection $(33.3 \%$, Table 6$)$. It is likely that the sample size tested at Heathrow was too small $(\mathrm{n}=10)$ to detect $B d$ infection in this pathway, but it is also possible that infection occurs after importation. There is a moderate likelihood of escape of live amphibians from research laboratories (Fig. 2, Box 7a), as indicated by the presence of feral Xenopus spp. in most countries where laboratories holding these animals exist. Release of contaminated water is also a concern via this pathway (Fig. 2, Box 7c). We estimated that $B d$ entry and exposure to amphibian populations via the laboratory amphibian trade is likely overall (Table 7).

Human consumption. The most common amphibian species reared for human consumption (Litho- bates catesbeianus) is an asymptomatic carrier of $B d$. Amphibians for the food trade are usually either wild-caught or reared in conditions that have inadequate disease control measures; therefore, the presence of $B d$ at the origin of this pathway is likely (Fig. 2, Box 1d) (Garner et al. 2006, Bai et al. 2010). Entry via this pathway is possible in countries such as the USA, where L. catesbeianus are imported live with an overall $B d$ infection prevalence of $62 \%$ (Schloegel et al. 2009). Importation of live L. catesbeianus into the EU is prohibited by EC Wildlife Trade Regulations. Additionally, frogs' legs must be skinned before importation into the EU from non-EU countries (DEFRA 2011a) or into the UK from any country (DEFRA 2011b). The trade in frogs' legs is primarily in frozen products (FAO 2011) and, as freezing kills $B d$ and the organism is confined to the skin in adult frogs, this processing should result in the absence of viable chytrid fungus (Fig. 2, Box 3c). As a result of these factors, $B d$ entry and exposure to amphibian populations via this pathway is very unlikely, but may increase if a significant live trade in other edible species is developed (Table 7).

Illegal animal movements. Since there are no restrictions on trade in non-CITES listed species (with the exception of Lithobates catesbeianus and Conraua goliath), illegal trade primarily consists of CITESlisted species for the pet trade (Fig. 2, Box 1e). The nature of this trade means that environmental conditions may be highly variable and not necessarily suitable for the survival of the amphibian or of $B d$. By its very nature, there is a high level of uncertainty associated with the volume and frequency of illegal movements and, dependent on this volume and frequency, $B d$ entry and exposure to amphibian populations via this route is moderately likely to likely (Table 7).

Unintentional introduction. One pathway for unintentional entry is via the importation of live amphibians as stowaways within agricultural and other produce (Fig. 2, Box 1f) (Marantelli \& Hobbs 2000). Although this has not been quantified for the UK, the likelihood of entry of $B d$ via this pathway is unlikely to be insignificant and should not necessarily be dismissed as a rare event. For example, it has been estimated that 50000 frogs are transported annually into Melbourne, Australia, in produce mostly from elsewhere in Australia (Amphibian Research Centre, http://frogs.org.au/arc/media.php). Other pathways of unintentional entry include the transport of water (e.g. used to transport fish or aquatic plants) and moist fomites (such as extracted riverbed gravel), which can act as carriers for the spread of viable zoospores (Fig. 2, Box 1g). There is a high level of 
uncertainty about the likelihood of entry and establishment via these pathways; namely, the likelihood of $B d$ being present at the origin, or whether infected frogs, contaminated water or fomites are likely to come into contact with native amphibians while any zoospores present are still viable. This pathway was assessed as being moderately likely overall (Table 7).

Probability of establishment and spread of $B d$ in the UK. After entry and exposure to captive and wild amphibian populations via the pathways identified above, the ability of $B d$ to establish and spread in natural environments depends on the conditions considered below.

Survival in the environment: Climate modelling has indicated that suitable conditions for the survival of $B d$ are widespread in the UK and, although survival and establishment are dependent on season, animal density and water quality, such establishment has already proved possible in at least one county, Kent (Cunningham et al. 2005). Imported amphibians capable of being $B d$ vectors are likely to be more variable in their climatic tolerance than native species and, although established populations of both Xenopus laevis and Lithobates catesbeianus have been found in the UK, many species found in the pet trade (e.g. tropical species) are unlikely to become established in the UK. $B d$ is able to survive in temperatures as low as $4^{\circ} \mathrm{C}$ (Piotrowski et al. 2004) or even possibly at freezing environmental temperatures when $B d$ is within host tissues (Gleason et al. 2008).

Mode of spread: Wave-like directional spread of $B d$ has been documented in Central and South America at rates of 25 to $282 \mathrm{~km} \mathrm{yr}^{-1}$ (Lips et al. 2008). Although mechanisms for such rapid spread are not yet fully understood, it seems that the maximum rate of natural spread of $B d$ is most likely to occur within its optimal temperature range $\left(12\right.$ to $\left.27^{\circ} \mathrm{C}\right)$ and along areas of uninterrupted suitable habitat, such as mountain chains and river valleys (Laurance et al. 1996, Lips et al. 2008). Anthropogenic mechanisms of spread, such as translocation of infected amphibians, moist substrate or other contaminated fomites, enable $B d$ to move more rapidly over long distances or past natural barriers (Speare et al. 2001). Amphibian translocation and reintroduction programmes provide opportunities for $B d$ spread by introducing amphibians directly into a suitable environment; thus, it is imperative to take appropriate prerelease quarantine and disease-screening measures (Cunningham 1996). As Bd can infect the keratinised mouthparts of anuran larvae in addition to the skin of adult amphibians, common practices, such as the collection of frogspawn/ tadpoles by school classes and the release of tadpoles or adults at sites other than the collection point, could aid the spread of this pathogen within the UK.

Host range and distribution of susceptible species: Available hosts for $B d$ in the UK include 7 native amphibian species and at least 10 invasive species. Several of the native species (e.g. Bufo bufo, Rana temporaria, Lissotriton helveticus) are widely distributed throughout the UK.

Detection of Bd infection: Once $B d$ becomes established at a local site, control relies on the detection of infected populations within a reasonable time to institute possible containment and control measures. Complex interactions between $B d$ exposure, infection and host response at different stages of development have been demonstrated experimentally in Bufo bufo and in field conditions in Spain, where mass mortalities of this species have occurred (Bosch \& Martinez-Solano 2006, Garner et al. 2009a). Infection outcomes also can be context dependent; in such cases, infected animals show no sign of disease under certain environmental conditions but exhibit high mortality rates under others (Burrowes et al. 2004, Walker et al. 2010). Detection of infection is additionally complicated by difficulties in detecting disease; outside the breeding season UK amphibian species are often cryptic, especially during the post-metamorphic life stage, which is when some UK native species are most likely to be most susceptible to amphibian chytridiomycosis. Even when diseased animals are detected, the relatively enigmatic clinical signs and rare occurrence of visible lesions (as reviewed by Fisher et al. 2009a) hinder recognition of $B d$ infection as the cause.

Summary of the probability of entry, establishment and spread of Bd in the UK: $B d$ entry is likely via the pet and laboratory trades, moderately likely to likely via illegal movements, moderately likely via the zoo trade and unintentional transfers and very unlikely via trade for human consumption (Table 7). $B d$ transfer from captivity to the wild may occur via the release or escape of infected live amphibians, movement of contaminated fomites and disposal of wastewater without disinfections. Overall, it was estimated that $B d$ entry and exposure to captive and wild amphibian populations is very likely. Suitable wild hosts and environmental conditions for $B d$ are widespread in the UK. Successful establishment and spread of $B d$ in natural environments in the UK is likely and moderately likely, respectively (Table 7).

Impact assessment. Given that entry, establishment and spread are likely overall, an impact assessment is required to identify any potential direct and indirect economic, environmental and/or social impacts. 
Direct impacts: $B d$ is only known to infect amphibians, so there are no public health, livestock or companion animal health impacts in the UK. Effects of $B d$ infection to an individual amphibian may range from no morbidity to death, depending on host species, dose and $B d$ strain (reviewed by Fisher et al. 2009a) and on environmental factors (Burrowes et al. 2004, Walker et al. 2010). Taking into account variations in $B d$ strain virulence (Fisher et al. 2009b), experimental studies with a selection of isolates detected in UK amphibian imports, zoos and laboratories would assist assessments of species-specific responses in UK native species. However, application of these results to wild situations would be complicated by temporal-spatial variations in ecological and environmental factors.

Amphibian chytridiomycosis has had a devastating effect on amphibian populations globally. Lips et al. (2006) estimated the disappearance of approximately $50 \%$ of amphibian species and $80 \%$ of individuals within 4 to 6 mo of $B d$ introduction to naïve sites in Panama. Although the susceptibility of most UK species is unknown, the potential exists for widespread, long-term population loss and extinction affecting multiple species, with serious ecosystem effects. As a carrier and reservoir of $B d$ infection, the invasiveness of species such as Lithobates catesbeianus is enhanced via parasite-mediated (apparent) competition (Anderson et al. 1986, Daszak et al. 2003). In addition, the presence of $B d$ in captive amphibian populations threatens endangered species breeding programmes through mortality and loss of genetic diversity (Banks et al. 2002).

Indirect impacts: The secondary economic costs of $B d$ infection can be significant. The Australian Government Department of Environment and Heritage has contributed several million dollars to research and management plans for amphibian chytridiomy- cosis (Skerratt et al. 2007). Government agencies are likely to suffer economic losses in the UK because of the costs of control and eradication, surveillance and monitoring and the possible introduction of enhanced biosecurity requirements. Amphibian breeders, the pet trade, zoos and conservation programmes will suffer because of costs associated with losses due to the morbidity and mortality of infected animals, and those related to the detection and treatment of infection, as well as the implementation of enhanced biosecurity measures.

When infection in the wild is identified, control measures can include the extermination of infected amphibian populations or their removal into captivity for treatment. The habitat can then be left fallow for a period of time and amphibian access excluded (DEH 2005). If $B d$ becomes established across a wider area, eradication without a high probability of severe collateral damage to the environment is unfeasible; therefore, early detection and containment is the preferred option.

Whilst difficult to quantify, economic impacts are likely to be at least moderate, and the potential effect on biodiversity is likely to be major and long lasting. The overall impact of the introduction of $B d$ to the UK is likely to be major.

\section{Section C: Conclusions of risk assessment}

Entry, establishment and spread of $B d$ to captive and wild amphibian populations in the UK is likely under current systems, and the overall impact is likely to be major. These results are consistent with a recent $B d$ risk assessment performed in The Netherlands (Spitzen-van der Sluijs \& Zollinger 2010). The use of a likelihood/impact matrix (Table 8) to assess the likelihood and impact of harmful biological, envi-

Table 8. Likelihood/impact risk estimation matrix. Entry, establishment and spread of $B d$ is likely and its impact is major; therefore, the overall risk estimation for the introduction of $B d$ to the UK is high (in bold). Organisms with unrestricted risk estimates exceeding 'very low' pose an unacceptable threat, and risk management measures are required

\begin{tabular}{|c|c|c|c|c|c|}
\hline \multirow{2}{*}{$\begin{array}{l}\text { Likelihood of entry, } \\
\text { establishment and spread }\end{array}$} & \multicolumn{5}{|c|}{ - Impact of entry, establishment and spread - } \\
\hline & Minimal & Minor & Moderate & Major & Massive \\
\hline Very unlikely & Negligible risk & Negligible risk & Negligible risk & Very low risk & Low risk \\
\hline Unlikely & Negligible risk & Negligible risk & Very low risk & Low risk & Moderate risk \\
\hline Possible & Negligible risk & Very low risk & Low risk & Moderate risk & High risk \\
\hline Likely & Very low risk & Low risk & Moderate risk & High risk & Extreme risk \\
\hline Very likely & Low risk & Moderate risk & High risk & Extreme risk & Extreme risk \\
\hline
\end{tabular}


ronmental and economic effects provided an overall estimate of risk. We acknowledge that incomplete data are available and our assumptions and recommendations are subject to change as new information arises. Despite such uncertainties, the overall risk estimation for the introduction of $B d$ to the UK through the importation of live amphibians is high. Since the unrestricted risk exceeds that which is acceptable or justifiable (the ALOP), risk management measures are required.

\section{Stage 3: Risk management}

A series of sanitary measures aimed at reducing the risk associated with the importation of $B d$ into the UK are presented in Table S2 in the Supplement (www.int-res.com/articles/suppl/d098p095_supp.pdf), and a subset of these measures are discussed below. The measures included are intended as suggestions, and full feasibility assessments are outside the scope of this study. Measures should be implemented at conceptual critical control points along the pathways, i.e. at importation, in captive populations and at points where $B d$ may spread from captive to wild amphibians and their habitats (either via fomites or $B d$-infected amphibians) (Fig. 2). Ideally, one or more methods should be selected that, if implemented, will reduce the likelihood of entry, establishment and spread of a $B d$ to an acceptable level.

Kriger \& Hero (2009) proposed the imposition of severe trade restrictions to mitigate the international spread of $B d$, whilst Garner et al. (2009b) suggested the use of $B d$-free accreditation programmes as an alternative measure with a greater likelihood of successful implementation. As the primary reason for importing amphibians into the UK is for the pet trade, the promotion of a consumer-driven, $B d$-free accreditation programme, such as the US Pet Industry Joint Advisory Council's (PIJAC) 'Bd-Free 'Phibs' campaign (www.pijac.org/projects), could be seen as a possible option. Measures that could be taken by importers under such a scheme may involve not mixing animals or water from different origins or sources, disinfecting wastewater before disposal and testing and quarantining imported animals. Although skin-swabbing to test for $B d$ infection is noninvasive, a negative result does not allow an animal to be declared free from infection and this, along with the costs and time delay in obtaining laboratory results, reduces the likelihood of routine testing being implemented. Mandatory pre- or post-import quarantine periods may be more pragmatic.

\section{DISCUSSION}

Infection with $B d$ has been detected in native and non-native invasive species in the wild in the UK, but it is not yet known whether the infection has become endemic to native species. While our results are preliminary and further studies are required, we have shown that approximately $3 \%$ of amphibians imported in non-aquatic consignments for the pet industry in 2007 were infected with $B d$, which was higher than the prevalence detected in the existing captive pet populations tested in the UK. After import, these amphibians are often transported to distribution centres where they may be held with other stock before distribution to pet shops and private collections across the UK. Also, Bd-infected amphibians were detected in zoo and laboratory populations in the UK. Although no aquatic amphibians with $B d$ infection were detected by sampling at Heathrow BIP or at pet shops in the UK, this may have been due to a collective small sample size from a number of separate consignments (with 10 animals being the largest sample tested in a single consignment), and thus an inability to detect a prevalence of less than around $34 \%$ with a $95 \%$ degree of confidence. Given that the previously known distribution of $B d$ in the UK was limited to a small number of zoo collections and a site in the county of Kent where $B d$ has since been eradicated, the presence of $B d$-infected amphibians in the pet trade and their likelihood of being widely distributed across the UK is of significant concern, and follow-up studies are urgently required.

We determined that current systems for recording amphibian imports into the UK underestimate the volume of non-EU trade 10-fold and that within-EU movements of non-CITES species are not recorded at all. TRACES is a regulatory and recording system for border control, but it can only track what is required by EU rules. As there are no requirements in the UK or in the EU for amphibians to be declared, their movements cannot be reliably traced by using this database. Each consignment entering the UK via a BIP is accompanied by a CVEDA. Although consignments might contain animals with different commodity codes (e.g. amphibians and reptiles), TRACES does not allow the assignment of multiple commodity codes on one CVEDA. As a result, the amphibian commodity code is only entered if the consignment consists solely of amphibians; in cases of mixed consignments the commodity code of the regulated commodity (fish or reptiles) is recorded. This limitation of the TRACES system is a primary reason for the discrepancy between recorded and actual amphibian movements. 
The presence of $B d$ in all pathways of the live amphibian trade, along with the sufficiently large volume of amphibian trade into the UK, makes the introduction of $B d$ into the UK natural environment via newly imported and current captive amphibians very likely under current systems. Notable entry and exposure pathway components with high likelihoods include release of amphibians from the pet or illegal trades, release of contaminated water and reintroduction of amphibians from captive breeding and rearing programs that have inadequate $B d$-screening and eradication protocols. The strict implementation of biosecurity measures is required to reduce this likelihood (Walker et al. 2008). In stark contrast to the situation in the USA (Schloegel et al. 2009), the likelihood of introduction of $B d$ into the UK via the trade in frogs for human consumption was determined to be low, primarily owing to an EU-ban on the importation of live Lithobates catesbeianus, the species most predominant in the human food trade, but also because of pre-import requirements of skinning frogs' legs. Establishment and spread of $B d$ within natural habitats will depend on the availability of suitable habitat adjoining the site of establishment, seasonal factors and human activities resulting in dispersal, but overall, it was considered likely that $B d$ will be able to establish and spread in the UK. Economic and environmental effects are expected and the overall impact is likely to be major.

The UK National Ecosystem Assessment (2011) recognised the economic value provided through ecosystem services and identified invasive species, including animal diseases, as a primary driver of change in UK ecosystem services over the past $60 \mathrm{yr}$. It states that 'effective conservation and sustainable use of ecosystems are critical for human well-being and a future thriving and sustainable green economy' (p. 42), and that regulations are central in effecting these aims. Under the Convention on Biological Diversity, the Bern Convention and EU Wildlife Trade Regulations, the UK government has a responsibility to prevent the introduction of, or control or eradicate those alien species that threaten ecosystems, habitats or native species.

Risk mitigation measures associated with the importation of amphibians have been proposed and rely on the application of a legislative framework that is recognised internationally. The inclusion of $B d$ in the OIE AAHC facilitates this and provides the opportunity for member states to apply restrictions on trade to protect against $B d$ introduction with imported amphibians. Practical issues, however, inhibit the implementation of such measures. For a member state to apply trade restrictions, it must declare freedom from $B d$ in either the whole country or specific zones. To do this it must meet 1 of 3 criteria: (1) have no susceptible species (which is highly unlikely as amphibians are widely distributed around the world) and have applied basic biosecurity conditions for a period of $2 \mathrm{yr}$, (2) have had no disease identified for a period of $10 \mathrm{yr}$ despite conditions being conducive to clinical expression of $B d$ infection and have applied biosecurity conditions for $10 \mathrm{yr}$ (though subclinical $B d$ infections cannot be detected without specific testing), or (3) have had basic biosecurity measures and a programme of targeted surveillance in place for $2 \mathrm{yr}$, with no detection of disease.

The required technical information on the definitions of clinical expression, approved methods of diagnostic testing, basic biosecurity measures and targeted surveillance programmes are currently not defined as, at the time of this writing, the relevant part of the Aquatic Manual has not yet been published. In addition, the requirements listed above make reference to disease rather than infection with the pathogen, which is clearly a more relevant basis for declaration of ' $B d$-free' status. Adoption of these OIE recommendations by individual member states (and, for its member countries, by the EU) is only required if they wish to achieve $B d$-free status.

Risk communication should be integrated throughout the risk analysis process. It is vital that potential stakeholders are identified early in the risk analysis process and that communication channels are established between stakeholders and decision makers to enable a flow of information and opinions regarding the hazards, risks and proposed measures. Representatives from government, public bodies, trade and industry associations, zoos and conservation organisations, pet shops, research laboratories, amphibian breeders and private owners were contacted throughout the course of the current risk analysis process and were invited to take part or voice suggestions or concerns. The wider community must be informed about amphibian chytridiomycosis and amphibian declines, existing legislation and regulations and the risks of transporting or releasing potentially infected amphibians, water and other transmitting agents.

$B d$ is present in newly imported and captive amphibians in the UK and is already established in wild amphibians in at least one site. The spread of $B d$ in the UK will depend on the availability of suitable habitat and hosts adjoining the site of establishment and on human activities that could facilitate dispersal or additional areas of release. Further studies on $B d$ prevalence and strain variation in imported amphib- 
ians and national surveys to determine the incidence and distribution of $B d$ infection in the UK are required in order to inform government policy for $B d$ control and mitigation and the development of a national management plan. Detection of one $B d$ strain in the UK should not deter ongoing biosecurity measures, given the possibility of the entry and establishment of exotic strains that are potentially more virulent (Fisher et al. 2009b). The inclusion of $B d$ in the AAHC and on the OIE list of notifiable diseases is a crucial step in determining the current global distribution of this pathogen and in limiting its further spread. Measures to mitigate the risks of $B d$ introduction are available; prioritisation and widespread implementation of these measures are required.

Acknowledgements. The authors are very grateful for the assistance provided by R. Quest and staff at the Heathrow Animal Reception Centre and by E. Shickle and staff from Animal Health at Heathrow. We thank S. Hall, J. Ircha and R. Davis (Department for Environment, Food and Rural Affairs), M. Perkins, T. Garner and M. Rendle (Zoological Society of London) and C. Newman (Reptile and Exotic Pet Trade Association) for information and technical support. Funding was provided by the Royal Veterinary College, the Zoological Society of London and the Zebra Foundation for Veterinary Zoological Education. Additionally, we appreciate the input from 2 anonymous reviewers, which contributed significantly to the manuscript.

\section{LITERATURE CITED}

Anderson RM, May RM, Joysey K, Mollison D and others (1986) The invasion, persistence and spread of infectious diseases within animal and plant communities. Philos Trans R Soc Lond B Biol Sci 314:533-570

Aplin K, Kirkpatrick P (2000) Chytridiomycosis in southwest Australia: historical sampling documents the date of introduction, rates of spread and seasonal epidemiology, and sheds new light on chytrid ecology. In: Speare R et al. (eds) Getting the jump! on amphibian disease. Conference and Workshop Compendium, 26-30 August 2000, Cairns, p 24 (Abstract). Available at www.jcu.edu. au/school/phtm/PHTM/frogs/GJKirk.htm

Bai C, Garner TWJ, Li Y (2010) First evidence of Batrachochytrium dendrobatidis in China: discovery of chytridiomycosis in introduced American bullfrogs and native amphibians in the Yunnan Province, China. EcoHealth 7: 127-134

Baker RHA, Black R, Copp GH, Haysom KA and others (2008) The UK risk assessment scheme for all non-native species. In: Rabitsch W, Essl F, Klingenstein F (eds) Biological invasions - from ecology to conservation. Neobiota $7: 46-57$

Baker RHA, Copp G, Hulme P, Thomas M, Black R, Hayson K (2005) UK non-native organism risk assessment scheme user manual, version 3.3. Department for Environment, Food, and Rural Affairs, London. Available at https:// secure.fera.defra.gov.uk/nonnativespecies/download Document.cfm?id=158 (accessed 14 April 2011)
Banks C, McCracken H, Natrass A (2002) Captive management and pathology of sharp snouted dayfrogs, Taudactylus acutirostris, at Melbourne and Taronga zoos. In: Frogs in the community. Proc Brisbane Symp Queensland Frog Society. Queensland Frog Society, Brisbane, p 94-102

Berger L, Speare R, Daszak P, Green D and others (1998) Chytridiomycosis causes amphibian mortality associated with population declines in the rain forests of Australia and Central America. Proc Natl Acad Sci USA 95: 9031-9036

Berger L, Marantelli G, Skerratt LF, Speare R (2005) Virulence of the amphibian chytrid fungus Batrachochytrium dendrobatidis varies with the strain. Dis Aquat Org 68: 47-50

Bielby J, Cooper N, Cunningham AA, Garner TWJ, Purvis A (2008) Predicting susceptibility to future declines in the world's frogs. Conserv Lett 1:82-90

> Bosch J, Martinez-Solano I (2006) Chytrid fungus infection related to unusual mortalities of Salamandra salamandra and Bufo bufo in the Penalara Natural Park, Spain. Oryx 40:84-89

> Boyle DG, Boyle DB, Olsen V, Morgan JAT, Hyatt AD (2004) Rapid quantitative detection of chytridiomycosis (Batrachochytrium dendrobatidis) in amphibian samples using real-time Taqman PCR assay. Dis Aquat Org 60:141-148

> Bradley GA, Rosen PC, Sredl MJ, Jones TR, Longcore JE (2002) Chytridiomycosis in native Arizona frogs. J Wildl Dis 38:206-212

Burrowes P, Joglar R, Green D (2004) Potential causes for amphibian declines in Puerto Rico. Herpetologica 60: 141-154

Covello VT, Merkhofer M (1993) Risk assessment methods: approaches for assessing health and environmental risks. Plenum Publishing, New York, NY

> Cunningham AA (1996) Disease risks of wildlife translocations. Conserv Biol 10:349-353

Cunningham AA, Garner TWJ, Aguilar-Sanchez V, Banks B and others (2005) Emergence of amphibian chytridiomycosis in Britain. Vet Rec 157:386-387

> Daszak P, Berger L, Cunningham AA, Hyatt AD, Green DE, Speare R (1999) Emerging infectious diseases and amphibian population declines. Emerg Infect Dis 5:735-748

Daszak P, Cunningham AA, Hyatt AD (2003) Infectious disease and amphibian population declines. Divers Distrib 9:141-150

Daszak P, Strieby A, Cunningham AA, Longcore JE, Brown C, Porter D (2004) Experimental evidence that the bullfrog (Rana catesbeiana) is a potential carrier of chytridiomycosis, an emerging fungal disease of amphibians. Herpetol J 14:201-207

DEFRA (Department for Environment Food and Rural Affairs) (2011a) Frogs' legs for human consumption (BAL IIN 3A). DEFRA, London. Available at www.defra.gov. uk/foodfarm/animaltrade/inports/iins/frog/bal3a.htm (accessed 14 April 2011)

DEFRA (Department for Environment Food and Rural Affairs) (2011b) Personal import rules database. DEFRA, London. http://importdetails.defra.gov.uk (accessed 16 June 2011)

DEH (Department of the Environment and Heritage) (2005) Threat abatement plan: infection of amphibians with chytrid fungus resulting in chytridiomycosis. Background document. DEH, Canberra. Available at www. environment.gov.au/biodiversity/threatened/publications/ 
tap/pubs/chytrid-background.pdf (accessed 29 June 2009)

- Drew A, Allen EJ, Allen LJS (2006) Analysis of climatic and geographic factors affecting the presence of chytridiomycosis in Australia. Dis Aquat Org 68:245-250

FAO (Food and Agriculture Organization) (2011) Cultured aquatic species information programme: Rana catesbeiana. UN FAO, Rome. Available at www.fao.org/fi/ website/FIRetrieveAction.do?dom=culturespecies\&xml= Rana_catesbeiana.xml (accessed 29 June 2009)

Fisher MC, Garner TWJ (2007) The relationship between the emergence of Batrachochytrium dendrobatidis, the international trade in amphibians and introduced amphibian species. Fungal Biol Rev 21:2-9

> Fisher MC, Garner TWJ, Walker S (2009a) Global emergence of Batrachochytrium dendrobatidis and amphibian chytridiomycosis in space, time, and host. Annu Rev Microbiol 63:291-310

Fisher MC, Bosch J, Yin Z, Stead DA and others (2009b) Proteomic and phenotypic profiling of the amphibian pathogen Batrachochytrium dendrobatidis shows that genotype is linked to virulence. Mol Ecol 18:415-429

- Garner TWJ, Perkins M, Govindarajulu P, Seglie D, Walker S, Cunningham AA, Fisher MC (2006) The emerging pathogen Batrachochytrium dendrobatidis globally infects introduced populations of the North American bullfrog, Rana catesbeiana. Biol Lett 2:455-459

> Garner TWJ, Walker S, Bosch J, Leech S, Rowcliffe MJ, Cunningham AA, Fisher MC (2009a) Life history tradeoffs influence mortality associated with the amphibian pathogen Batrachochytrium dendrobatidis. Oikos 118:783-791

Garner TWJ, Stephen I, Wombwell E, Fisher MC (2009b) The amphibian trade: bans or best practice? EcoHealth 6: 148-151 \& author reply, p 152

Gleason FH, Letcher PM, McGee PA (2008) Freeze tolerance of soil chytrids from temperate climates in Australia. Mycol Res 112:976-982

> Goka K, Yokoyama J, Une Y, Kuroki T and others (2009) Amphibian chytridiomycosis in Japan: distribution, haplotypes and possible route of entry into Japan. Mol Ecol 18:4757-4774

Holsbeek G, Mergeay J, Hotz H, Plötner J, Volckaert F, De Meester L (2008) A cryptic invasion within an invasion and widespread introgression in the European water frog complex: consequences of uncontrolled commercial trade and weak international legislation. Mol Ecol 17: 5023-5035

> Holsbeek G, Mergeay J, Volckaert F, De Meester L (2010) Genetic detection of multiple exotic water frog species in Belgium illustrates the need for monitoring and immediate action. Biol Invasions 12:1459-1463

Hyatt AD, Boyle DG, Olsen V, Boyle DB and others (2007) Diagnostic assays and sampling protocols for the detection of Batrachochytrium dendrobatidis. Dis Aquat Org 73:175-192

IUCN (International Union for Conservation of Nature) (2011) IUCN red list of threatened species. Available at www.iucnredlist.org (accessed 16 September 2010)

> James TY, Litvintseva AP, Vilgalys R, Morgan JAT and others (2009) Rapid global expansion of the fungal disease chytridiomycosis into declining and healthy amphibian populations. PLoS Pathog 5:e1000458

> Johnson ML, Speare R (2003) Survival of Batrachochytrium dendrobatidis in water: quarantine and disease control implications. Emerg Infect Dis 9:922-925
Johnson ML, Berger L, Philips L, Speare R (2003) Fungicidal effects of chemical disinfectants, UV light, desiccation and heat on the amphibian chytrid Batrachochytrium dendrobatidis. Dis Aquat Org 57:255-260

Kielgast J, Rödder D, Veith M, Lotters S (2010) Widespread occurrence of the amphibian chytrid fungus in Kenya. Anim Conserv 13:36-43

Kilpatrick AM, Briggs CJ, Daszak P (2010) The ecology and impact of chytridiomycosis: an emerging disease of amphibians. Trends Ecol Evol 25:109-118

Kriger KM, Hero JM (2007) The chytrid fungus Batrachochytrium dendrobatidis is non-randomly distributed across amphibian breeding habitats. Divers Distrib 13: 781-788

Kriger KM, Hero JM (2009) Chytridiomycosis, amphibian extinctions, and lessons for the prevention of future panzootics. EcoHealth 6:6-10

Kriger KM, Hero JM, Ashton KJ (2006a) Cost efficiency in the detection of chytridiomycosis using PCR assay. Dis Aquat Org 71:149-154

Kriger KM, Hines HB, Hyatt AD, Boyle DG, Hero JM (2006b) Techniques for detecting chytridiomycosis in wild frogs: comparing histology with real-time Taqman PCR. Dis Aquat Org 71:141-148

Kriger KM, Ashton K, Hines HB, Hero JM (2007) On the biological relevance of a single Batrachochytrium dendrobatidis zoospore: a reply to Smith (2007). Dis Aquat Org 73:257-260

Laurance W, McDonald K, Speare R (1996) Epidemic disease and the catastrophic decline of Australian rain forest frogs. Conserv Biol 10:406-413

Lips KR, Brem F, Brenes R, Reeve J and others (2006) Emerging infectious disease and the loss of biodiversity in a Neotropical amphibian community. Proc Natl Acad Sci USA 103:3165-3170

Lips KR, Diffendorfer J, Mendelson JR, Sears MW (2008) Riding the wave: reconciling the roles of disease and climate change in amphibian declines. PLoS Biol 6:e72

Longcore JE, Pessier A, Nichols D (1999) Batrachochytrium dendrobatidis gen. et sp. nov., a chytrid pathogenic to amphibians. Mycologia 91:219-227

Lötters S, Kielgast J, Bielby J, Schmidtlein S, Bosch J (2009) The link between rapid enigmatic amphibian decline and the globally emerging chytrid fungus. EcoHealth 6: 358-372

Marantelli G, Hobbs R (2000) Disease vectors and the community: from lost frogs to frog friendly gardens - How do we help frogs while containing disease spread? In: Speare R et al. (eds) Getting the jump! on amphibian disease. Conference and Workshop Compendium, 26-30 August 2000, Cairns p 49 (Abstract). Available at www. jcu.edu.au/school/phtm/PHTM/frogs/GJHobbs.htm

> Mendelson JR III, Lips KR, Gagliardo RW, Rabb GB and others (2006) Confronting amphibian declines and extinctions. Science 313:48

Nichols DK, Lamirande EW, Pessier AP, Longcore JE (2001) Experimental transmission of cutaneous chytridiomycosis in dendrobatid frogs. J Wildl Dis 37:1-11

OIE (Office International des Epizooties) (2006) Report of the meeting of the OIE Aquatic Animal Health Standards Commission. OIE, Paris

OIE (Office International des Epizooties) (2010a) Aquatic animal health code. OIE, Paris. Available at www.oie.int/ en/international-standard-setting/aquatic-code/accessonline/ (accessed 16 June 2011) 
OIE (Office International des Epizooties) (2010b) Handbook on import risk analysis for animals and animal products, Vol 1. Introduction and qualitative risk analyses, 2nd edn. OIE, Paris

Picco AM, Collins JP (2008) Amphibian commerce as a likely source of pathogen pollution. Conserv Biol 22: 1582-1589

Piotrowski JS, Annis SL, Longcore JE (2004) Physiology of Batrachochytrium dendrobatidis, a chytrid pathogen of amphibians. Mycologia 96:9-15

Rachowicz L, Hero JM, Alford R, Taylor J and others (2005) The novel and endemic pathogen hypotheses: competing explanations for the origin of emerging infectious diseases of wildlife. Conserv Biol 19:1441-1448

Raverty S, Reynolds T (2001) Cutaneous chytridiomycosis in dwarf aquatic frogs (Hymenochirus boettgeri) originating from southeast Asia and in a western toad (Bufo boreas) from northeastern British Columbia. Can Vet J 42:385-386

Reed K, Ruth G, Meyer J, Shukla S (2000) Chlamydia pneumoniae infection in a breeding colony of African clawed frogs (Xenopus tropicalis). Emerg Infect Dis 6:196-199

Retallick RWR, Miera V (2007) Strain differences in the amphibian chytrid Batrachochytrium dendrobatidis and non-permanent, sub-lethal effects of infection. Dis Aquat Org 75:201-207

Ron S (2005) Predicting the distribution of the amphibian pathogen Batrachochytrium dendrobatidis in the New World. Biotropica 37:209-221

Rowley JJL, Chan SKF, Tang WS, Speare R and others (2007) Survey for the amphibian chytrid Batrachochytrium dendrobatidis in Hong Kong in native amphibians and in the international amphibian trade. Dis Aquat Org 78:87-95

Schlaepfer M, Hoover C, Dodd C Jr (2005) Challenges in evaluating the impact of the trade in amphibians and reptiles on wild populations. Bioscience 55:256-264

Schloegel LM, Picco A, Kilpatrick A, Davies A, Hyatt A, Daszak P (2009) Magnitude of the US trade in amphibians and presence of Batrachochytrium dendrobatidis and ranavirus infection in imported North American bullfrogs (Rana catesbeiana). Biol Conserv 142: $1420-1426$

Schloegel LM, Daszak P, Cunningham AA, Speare R, Hill B (2010) Two amphibian diseases, chytridiomycosis and ranaviral disease, are now globally notifiable to the World Organization for Animal Health (OIE): an assess-

Editorial responsibility: Alex Hyatt, Geelong, Victoria, Australia ment. Dis Aquat Org 92:101-108

Skerratt L, Berger L, Speare R, Cashins S and others (2007) Spread of chytridiomycosis has caused the rapid global decline and extinction of frogs. EcoHealth 4:125-134

Smith KG (2007) Use of quantitative PCR assay for amphibian chytrid detection: comment on Kriger et al. (2006a,b). Dis Aquat Org 73:253-255

Speare R, Core Working Group of Getting the Jump on Amphibian Disease (2001) Nomination for listing of amphibian chytridiomycosis as a key threatening process under the Environment Protection and Biodiversity Conservation Act 1999. In: Speare et al. (eds) Developing management strategies to control amphibian diseases: decreasing the risks due to communicable diseases. School of Public Health and Tropical Medicine, James Cook University, Townsville, p 186-208

Spitzen-van der Sluijs AM, Zollinger R (2010) Risk assessment on the American bullfrog and the fungus Batrachochytrium dendrobatidis. Stichting RAVON, Nijmegen

St-Hilaire S, Thrush M, Tatarian T, Prasad A, Peeler E (2009) Tool for estimating the risk of anthropogenic spread of Batrachochytrium denrobatidis between water bodies. EcoHealth 6:16-19

Thrush MA, Murray AG, Brun E, Wallace S, Peeler E (2011) The application of risk and disease modelling to emerging freshwater diseases in wild aquatic animals. Freshw Biol 56:658-675

UK National Ecosystem Assessment (2011) UK National Ecosystem Assessment: synthesis of key findings. UN Environment Programme, World Conservation Monitoring Centre, Cambridge. Available at http://archive. defra.gov.uk/environment/natural/documents/UKNEA_ SynthesisReport.pdf (accessed 9 June 2011)

Walker SF, Salas MB, Jenkins D, Garner TWJ and others (2007) Environmental detection of Batrachochytrium dendrobatidis in a temperate climate. Dis Aquat Org 77: 105-112

Walker SF, Bosch J, James TY, Litvintseva AP and others (2008) Invasive pathogens threaten species recovery programs. Curr Biol 18:R853-R854

Walker SF, Bosch J, Gomez V, Garner TWJ and others (2010) Factors driving pathogenicity vs. prevalence of amphibian panzootic chytridiomycosis in Iberia. Ecol Lett 13: 372-382

Weldon C, du Preez L, Hyatt A, Muller R, Speare R (2004) Origin of the amphibian chytrid fungus. Emerg Infect Dis 10:2100-2105

Submitted: November 15, 2010; Accepted: November 7, 2011 Proofs received from author(s): February 9, 2012 